\title{
An Overview on Adverbial Locutions More Words in Albanian Language
}

\author{
Prof. As. Dr. Haredin Xhaferi \\ Faculty of Peshkopi \\ University "Alexander Moisiu" \\ Durres \\ ALBANIA
}

\begin{abstract}
The object of this article is to describe the formation of locutions formed by many words, noting the value of their semantics. This group locutions is not large, however, they show great interest for structural and semantic diversity. These locutions are treated in grammar and different studies not as a separate group and not in detail. In the article they will be treated according to the elements that make up their structure. These elements are words with features lexicon - grammar different and have different degrees of stability. The use ratio of meaningful words, words not meaningful in these structures is different. Largest number consists locutions that are formed from equal number of words of the two groups. Meaningful words these locutions are names, adverbs and numerals rare; not meaningful words are the conjunction, preposition or particles. They can stand before a meaningful word or in between them. Meaningful words are reports of equality between them. Locutions having the structure unequal number of words meaningful and non-meaningful words are scarce. Among the meaningful words of this type locutions reports are mixed. The first two elements are scoring words about addiction.
\end{abstract}

Keywords: phrase, adverb, structure, element, meaningful words, words not meaningful, value semantics, semantic relationships

\section{Introduction}

Locutions are popular in different languages, but are not treated as separate units language. For them there is a general concept as open structures that form a whole language with the value and function of a word, but there is still a stand alone nature, the criteria for recognition and setting them etc. These units are reflected in grammar with parts of speech, which have the same value semantics and lexicology are included with phraseological units. Special studies for these units so far have been limited and have not been sufficient to differentiate and to be differentiated from other linguistic units, especially units that are closest to them: the attached words, the free compound words and phraseological units.

Locutions that are semantically equivalent fixed parts, are treated in Albanian Grammatology, although the words slave "have been, as it were, on the outskirts of grammatical studies. " $E$. Lafe, Lidhëzat te libri i parë shqip). In some researchers locutions are treated with the appropriate parts of speech or analyze individual types of any group. (See A. Xhuvani, Orgjina dhe formimi i ndajfoljeve në shqipe; E. Hysa, Ndajfolja në gjuhën e sotme shqipe; M. Samara, Parafjalët në shqipen e sotme (Vështrim leksiko - semantik); M. Çeliku, Lokucionet parafjalore emërore në gjuhën letrare shqipe; Sh. Demiraj, Rreth ndajfoljëzimit (adverbializimit) të disa formave gramatikore dhe të disa togjeve të tipit parafjalë + emër etc. )

The most comprehensive treatment of these locutions is made in scientific works of the Academy of Sciences, where locutions noting that occur primarily in fixed parts of speech. (Fonetika dhe gramatika e gjuhës së sotme letrare shqipe; Gramatika e gjuhës shqipe). Identify them easily on any researcher explained with a much higher degree of reliability of the constituent elements. (A. Spahiu, A përbëjnë lokucionet një mënyrë të veçantë fjalëformimi?)

Locutions the value of a constant part are added to the creation of many new units worth prepositions, conjunctions, adverbs etc. This phenomenon is seen as Albanian trend for increased analytical structures. (M. Domi, Procese dhe prirje të zhvillimit të strukturës sintaksore të gjuhës) Alongside this trend, mainly the last century, is doing significantly, especially in recent decades, the trend towards synthesize these units. Many of them today use two forms: as locutions and as a single word. Any researcher thinks that one should avoid this use, being used as words. (See more about this process $\mathrm{L}$. Buxheli, Çështje të shkrimit të fjalëve të përngjitura dhe të disa strukturave analitike)

Locutions the value of a constant part of more extensive compared with the value of a variable part. These locutions have adverbial value, a prepositions, a connecter, a particle or an interjection. Adverbial locutions are varied as the structure, and semantics. 
In this article will be considered a special type adverbial locutions worth, which have the structure more than three words. Words that make up, are different categories lexicon - grammar. Writing will make a more specific and more detailed groups and subgroups that constitute locutions of this type, will highlight the diversity of structural and semantic value. Based on the degree of reliability of the constituent elements and the grammatical and semantic changes of these elements, intended for a more precise definition of these units. This type locutions not treated as a special formation.

Early scholars are not mentioned these locutions. J. Thomi enough of the locutions this type are treated as adverbial phraseological units with coordination kopulative and not kopulative (me sot e me nesër, në këmbë e në dorë), the coordination of the two limbs no equivalent of the structure (fill e për pe, orë e pa kohë, rrallë e për mall), as phraseological constructions starting with a preposition (me rrënjë e me degë, me hir e me pahir, me mish e me shpirt, për sy e faqe, pa çak pa bam etc. ) (Një klasifikim i frazeologjizmave me vlerë ndajfoljore në gjuhën shqipe) E. Hysa in his study of the formation of adverbs treated as a special type only a subset of them, formed by the preposition nga + noun in the nominative + the preposition në + name in the objective case, as: nga çasti në çast, nga dita në ditë, nga koha në kohë etc. (Formimi i ndajfoljeve). This group is also reflected in Fonetika dhe gramatika e gjuhës së sotme letrare shqipe and Gramatika e gjuhës shqipe I.

\section{Classification}

Locutions formed from more than three words have to structure meaningful and non-meaningful words, which belong to different parts of speech.

\section{Locutions formed by two meaningful words and two non-meaningful words}

Locutions of this group are different from the order of the components. Words not meaningful to these locutions may precede or meaningful words can stand between them.

1. Locutions formed from non-meaningful words + meaningful word + non-meaningful word + meaningful word. Constitute the group had. By category lexicon - grammar meaningful words, these structures are different.

1. 1. Locutions formed by the preposition + noun + preposition + noun have the structure of two forms of the same name or two different names. No meaningful words may be the same preposition, two different preposition or a preposition and a conjunction.

a. Locutions formed by the preposition + noun + preposition + the same name are at somewhat rich. The locutions having to repeat a name structure, forms of names of these structures are preceded by the preposition different. The first form has formed heap on the racial preposition names, showing the initial time goal while platoon formed by the second form of the name of the racial accusative preposition shows the final target. None of these clusters does not work out locution. All locution said time relationship for an action or process that lasts or will be soon. Such are: nga dita në ditë, nga java në javë, nga muaji në muaj, nga viti në vit, nga brezi në brez, nga çasti në çast, nga ora në orë, nga minuta në minutë etc. For example. Arable land surfaces added nga viti në vit. Made of genuine occupation, which in time became almost inherited nga brezi në brez in the form of dynasties. At the time I felt afraid for delaying loved and anxietly for his achievement nga çasti në çast,, he heard behind a naughty tune got to sing. Expected nga ora në orë flow of people into the hut and did not want to hear what was outside.

b. Locutions formed by the preposition + noun + preposition + noun are slim. The structure of these locutions are two names with different meaning, before whom are using a case preposition or different cases. Locution is composed of two platoons preposition + noun.

- Locutions me rrënjë, me dhëmballë; pa nam, pa nishan etc. are formed by two different names with or without semantic links, preceded by the same preposition. These structures have not reached a high degree of consistency. Platoons preposition + noun to make up, can also be used separately. Second Platoon off locution expresses the same relationship 
with the height of the first, while within the locution used more in the sense amplifier. All shows strictly locution, safe, hairsplitting. For example. - For Seferin will talk much, that I know me rrënjë, me dhëmballë, - Myrto said.

- Locutions nga koka te këmbët, nga koka te thembrat etc. are formed by two different names, which designate part of a whole. These locutions express spatial relationships within the whole. Each separate platoons not work. First platoon said starting point of action, while the second platoon point of completion. All locution expresses spatial relationships defined. For example. I thought Yllin, his condition, when the manager broke the conversation at the table and felt the shame of the whole glow nga koka te këmbët. I threw a look nga koka te thembrat dand said not a word.

1. 2. Locutions formed by the preposition + adverb + preposition + adverb have two different structure, which are preceded by the same preposition. Adverbs show close periods. Locution limbs are equal ratios. These locutions express a short deadline indefinitely: me sot, me nesër; me tani, me pastaj etc. For example. They are being taught these people for centuries, has made relations with officials to process a particular position. We can not change them me sot, me nesër. These structures can also be used with the conjunction e: me sot e me nesër, me tani e me pastaj etc.

1. 3. Locutions formed by the preposition + numeral + preposition + numeral are quite rare. Such is the locution pa një, pa dy, who has two clusters structure formed by two different numerals, preceded by a preposition without. Each separate platoons not work. All said locution way associated with the mode of coercion, of necessity. For example. - You will go for us? - I am, pa një pa dy.

1. 4. Locutions formed by the preposition + noun + connecter + adverb are scarce. In these locutions an abstract name commonly used, preceded by the preposition to and followed by the conjunction of. The second limb is adverb sipër, which has completely lost its meaning and serves to update the time. Locution semantically brunt keeps limb names. Locution performs the same function that carries out the locution nominal platoon. Such are: në vrap e sipër, në punë e sipër, në gjumë e sipër, në rrëmujë e sipër, në sherr e sipër, në rrugë e sipër, në bisedë e sipër etc. For example. More than anything now drives the anger and walking, në vrap e sipër, break apart teeth somehow blackberries to quench hunger. The matches were extinguished në rrugë e sipër and he lit another. Në bisedë e sipër on also mentioned an earlier altercation, which I thought was forgotten.

\section{Locutions formed by meaningful word + non-meaningful words + non-meaningful words + meaningful words}

Branding words of such locutions can be the same word repeated or may be two different units lexicon - grammar. Locution limbs are equal reports state groups. The second limb expresses that said first limb more reinforced and the major share of the locution meaning. Within this structure, used a word service with limiting or denying function.

2. 1. Locution formed by name + connecter + preposition + noun are not rich group. They consist of a name or two names repeated with different meaning.

a. Locutions formed by name + connecter + preposition + the same name are numerous. The name appears in the form of outstanding free even when repeated. The second limb in these structures is preceded by the preposition without which gives meaning denying the limb, but retains locution unspecified affirmative sense.

- Locutions udhë e pa udhë, vend e pa vend etc. are formed by repetition of a topical name in the form of free outstanding. These locutions show impersonal place where performed an action that lasts. For example. The night was very dark and we have passed udhë e pa udhë.

- These locutions can show the action indefinitely, as well as on the queue locutions radhë e pa radhë, vend e pa vend, rast e pa rast etc. For example. Director, having an experience of thirty years as a miner, thought he knew everything and vend e pa vend interfere with bestiality. Baca Dan did not show casually rast e pa rast, those his stories, he begged us not to hear us, is prayed in the village told us.

- Locutions kohë e pa kohë, orë e pa orë, vakt e pa vakt etc. have to structure a name repeated time. They show indefinite period of time when performed an action that lasts or rolling. For example. See that his gaze was distracted again and remain the aunt orë e pa orë.

Any structure is formed by two different names, first from the perspective synonymous, as orë e pa kohë etc. For example. Worked orë e pa kohë and hate fill of bread. 
b. Locutions formed by name + connecter + preposition + noun synonymous are rare. Such are locutions synonyms fill e për pe, fije e për pe. In these structures before the second name comes a preposition of accusative and formally it passes in that gown, however the equity stored. Platoon preposition + noun no use of autonomous elements have lost the sense and the ability to bond with other words. He holds the major share of the locution semantics. For example. Then he had asked fije e për pe on livestock.

2. 2. Locutions formed by name + connecter + preposition + adverb (a heap adverbial) are quite rare. In the second limb structure performs the function amplifier and is defining the meaning of the locution. These locutions express limited relationship. They show of action: fije e nga njëfije, çikë e nga njëçikë etc. For example. Çikë e nga njëçikë, every day, for years, he had thrown out heart excitement, interest in small things, that once filled her life. Platoons një çikë, një fije today presented with features of a word attached. Imposition of their component elements become detached, without pause. Name and numerator have lost their special meaning and function together as a single word.

2. 3. Locutions formed by the adverb + connector + particle + adverb constitute rich group. In these structures the second adverb could be a repeat of the adverb form of the first or another adverb. It necessarily preceded by particles more. The second limb bears the brunt of the locution semantic and expressed increasing spatial dimensions, dimensions time etc. or the degree of intensity or quality of an action that lasts. When adverb is not repeated as the second limb out an amount adverb that adds, magnifies what first adverb said: thellë e më thellë, tej e më tej, plot e më plot, vonë e më vonë, herët e më herët, lart e më lart, poshtë e më poshtë, sipër e më sipër, andej e më andej, ngadalë e më ngadalë, rrallë e më rrallë, shpejt e më shpejt, mirë e më mirë, qetë e më qetë, shumë e më shumë, keq e më keq, fort e më fort, gjithmonë e më shumë, gjithnjë e më shumë, gjithmonë e më tepër, gjithnjë e më tepër etc. For example. Nodded a couple - three times, as if beating with a heavy hammer his pain, to enter thellë e më thellë into the heart. Jokes its long now grabbed marshes and, if they had been studded stones, throw Pelt on its surface paving, was kissed hip - hop site and brought tej e më tej, giving more and more power. Ibish mention it rrallë e më rrallë and once removed it altogether, it seemed long. Editors of magazines expect more gjithmonë e më tepër with the warmest smile of compassion.

\section{Locutions formed by three meaningful words and a word not meaningful}

Are few in comparison with those of the first group. Meaningful words such locutions structures are equal or dependency ratios. Word not meaningful can be a go or a preposition.

1. Locutions formed by meaningful word + the conjunction e + words meaningful + meaningful word or vice versa does not constitute the majority.

a. Locutions formed by meaningful word + the conjunction e + words meaningful + meaningful word have the first meaningful words an adverb, followed by the conjunction $e$ and a phrase with qualifiers relationship. Such are locutions sot e gjithë ditën, sot e kësaj dite, këtu e një vit (më parë), aty e një muaj, njëherë e një kohë etc. , which first element a time adverb or country adverb the sense of time. These locutions express general time relationship or show a finite time limit. For example. What happened that day winter scare me even sot e kësaj dite when I remember. With Mustafa's eaten the assembly comes as njëherë e një kohë and was unfortunate that had fallen on the neck.

b. Locutions formed from meaningful word + meaningful word + conjunction e + meaningful word are rare. Such mention locutions një herë e mirë, një herë e përgjithmonë etc. , which indicate a safe or performing a final action. For example. Like I said, - said Selo, - better to die një herë e mirë, than pieces - pieces. To eradicate një herë e përgjithmonë different political nests had entered into the army, I ordered the demolition of the old army organization.

2. Locutions formed by meaningful word + word meaningful + preposition + meaningful words are few. Locutions such as: një ditë prej ditësh, një natë prej netësh, një ditë me diell, një natë me hënë, një natë pa hënë etc. The heap formed by two words meaningful phrase functions as outside these structures. Indefinite pronoun një and name ditë have weakened their meaning. This heap has the major share of the locution semantics. Meaningful third word is a name preceded by a preposition. Both elements retain lexical meaning. Name functions as a descriptor is first name, adding an additional feature generalists, not very important for the semantics of the locution. Locutions such as: një ditë prej ditësh, një natë prej netësh, një ditë me diell, një natë me hënë, një natë pa hënë etc. For example. Gathered again një ditë me diell and chose a new task force. But the insistence of friends and acquaintances of my best pushed me një ditë prej ditësh to get into a trial. 


\section{Locutions formed by two meaningful words and three not meaningful words}

Are a small group. Meaningful words are nouns, numerals, adverbs.

1. Locutions meaningful words formed from the same category lexicon - grammar. Meaningful words can be two forms of a name or two names synonymous, antonyms or other meanings.

a. Locutions formed by the preposition + noun + connecter + preposition + the same name are numerous. Locutions me të drejtë e pa të drejtë, me punë e pa punë, me shkak e pa shkak, me vend e pa vend, me kohë e pa kohë, me vakt e pa vakt etc. have in their structure two platoons formed by the repetition of a name, preceded by the antonyms prepositions, which give them positive and negative sense, while all locution affirmative sense. Two platoons are associated with a concerted connecter. These locutions express approach, with the idea of acceptance, approval or consent without full conviction, with suspicion: - Me të drejtë e pa të drejtë secretaries orders broadcast executives - said Aranit and came to trying the door. Submergement opposites had their own expressions and concerned me vend e pa vend.

The conjunction e these structures can be replaced by segregation conjunctions a or apo and locution gives an idea of the end of an action or process, regardless of the path chosen: me të drejtë a (apo) pa të drejtë, me punë a (apo) pa punë etc. For example. So Ismail beut ... did not like to stay in the municipality and people who me punë a pa punë needed to meet the head of state, came in his private apartment.

b. Plenty locutions are formed by two names synonymous, antonyms or other meanings, which form clusters with the same preposition within the locution. Second platoon within the structure of locution a feature reinforces the relationship expressed by the first platoon, establishes a relationship of coercion, of necessity etc. All locution serves to show:

- Manner of action: me të urtë e me të butë, me të mirë e me të butë, me thonj e me dhëmbë, me hir e me pahir, me këmbë e me duar, me pe e me gjilpërë, me lak e me gjak, me bukë e me kripë etc. For example. Mystehaku conversed me këmbë e me duar with Fuzuliun.

- Feature a state, without pinch saw mole; pa çikë e pa nishan; as në det, as në breg; as në qiell, as në tokë; as në mend, as në fiqir etc. For example. Lost pa çikë e pa nishan.

In some cases, a or apo conjunctions used, however, the relationship does not change: me hir apo (a) me pahir, me të drejtë apo (a) me të padrejtë etc. For example. Such rivalry nor could have existed until 1912, if it were not made me hir ose me pahir from Austria - Hungary error and mistakes.

2. Few locutions have to structure the heap numeral or indefinite pronoun + a time name, followed by the conjunction $e$ and by an adverb, preceded by particle më. The conjunction does not perform its function syntax and is an important element in the structure of locution.

- Locutions një orë e më parë, një sahat e më parë, një ditë e më parë etc. express a circumstance of time in which conducted an expedited action. The phrase një orë më parë without conjunction has the "one hour before the moment of discourse or a particular instant of time. " Constituent elements in these structures have lost their special meaning. This seems also to use the adverb before the first form. For example. With the tail of the eye saw how hurry all finished një orë e më parë, as they leave the water in the groove. Everyone wanted the situation created to end një sahat e më parë.

- Locutions çdo ditë e më shumë, çdo herë e më shumë, çdo ditë e më tepër, çdo herë e më tepër etc. time relationship express an action that is performed with high intensity. For example. We were in the last year of economics, accounting branch and my literary inclinations had long since turned çdo ditë e më shumë from the branch where parents had liked me to push through.

\section{Conclusion}

From the above analysis it appears that locutions adverbial are quite diverse from the structure and semantic values. This study can not be considered completed. Other studies are needed to become more distinct as those of other groups of locutions. Treatment as wide as the most comprehensive of these locutions helps to determine their place in the grammar of the various language texts and to reflect the different vocabularies. 


\section{References}

Buxheli, L. , Çështje të shkrimit të fjalëve të përngjitura dhe të disa strukturave analitike, Shqipja në etapën e sotme: politikat e përmirësimit dhe të pasurimit të standardit, 2011

Çeliku, M. , Lokucionet parafjalore emërore në gjuhën letrare shqipe, Çështje të gramatikës së sotme shqipe, II, 1975

Demiraj, Sh. , Rreth ndajfoljëzimit (adverbializimit) të disa formave gramatikore dhe të disa togjeve të tipit parafjalë + emër, Çështje të fonetikës dhe të gramatikës së gjuhës shqipe, 1972

Domi, M. , Procese dhe prirje të zhvillimit të strukturës sintaksore të gjuhës, Vepra I, Studime sintaksore, 2013

Fonetika dhe gramatika e gjuhës së sotme letrare shqipe, II 1976

Gramatika e gjuhës shqipe, I, 1995

Hysa, E. , Formimi i ndajfoljeve, Çështje të fonetikës dhe të gramatikës së gjuhës shqipe, 1972

Hysa, E. , Ndajfolja në gjuhën e sotme shqipe, Studime filologjike, 1, 1970

Lafe, E. , Lidhëzat te libri i parë shqip, Studime filologjike, 4, 1971

Samara, M. , Parafjalët në shqipen e sotme (Vështrim leksiko - semantik), 1999

Spahiu, A. , A përbëjnë lokucionet një mënyrë të veçantë fjalëformimi? Gjuha jonë, 1 - 4, 2005

Thomai, J. , Një klasifikim i frazeologjizmave me vlerë ndajfoljore në gjuhën shqipe, Studime filologjike, 1, 1969

Xhuvani, A. , Orgjina dhe formimi i ndajfoljeve në shqipe, Aleksandër Xhuvani, Vepra I, 1980 